\title{
On the Paths to Cultivate International Talents under the Background of the Silk Road Economic Belt and the $21^{\text {st }}$ Century Maritime Silk Road
}

\author{
Li Xiaolong \\ School of Fashion Engineering \\ Jiangxi Institute of Fashion Technology \\ 576816683@qq.com
}

\begin{abstract}
The initiative of the Silk Road economic belt and the $21^{\text {st }}$ century maritime Silk Road not only brings us new opportunities for economic development but also brings us new challenges to our talent market. The key to cultivate qualified international talents lies in the cultivation of training cross-cultural communication talents with high quality and multi-skills. The paper states the connotation of high--quality and multi-skills and cross--cultural communication, analyzes the present talents market situation in our country, and discusses the paths to cultivate the type of the talents. There is no doubt that the cultivation of the qualified international talents mentioned above need the joint efforts from universities, enterprises, government and society.
\end{abstract}

Keywords-one belt one road; talent cultivation; human resources; cross-cultural communication talents

\section{INTRODUCTION}

"One belt, one road” means the Silk Road economic belt and the $21^{\text {st }}$ century maritime Silk Road which was proposed by president Xi Jinping in September and October in 2013. The strategy concept of the Silk Road economic belt and the $21^{\text {st }}$ century maritime Silk Road aims at actively developing economic co-operation partnership with the countries along the ancient Silk Road, jointly builds the economic community, fate community and responsibility community of mutual believing in politic, integration in economic and tolerance in culture. The Silk Road economic belt and the $21^{\text {st }}$ century maritime Silk Road turn to promote the free flow of the economic factors with order, efficient allocation of resources and deep integration of market. The Silk Road economic belt and the $21^{\text {st }}$ century maritime Silk Road covers more than 60 countries, runs through mainland Europe, Asia and Africa, gets to the western Asia and the Middle Asia and Europe Circle in the west, connects to the Asia-Pacific Circle. The countries along the way cooperate in financial, sources, communication, agriculture, forestry, animal husbandry and fishery industry and emerging industry containing new-era information technology, biology, sea, new energy and materials.

Due to the progressively depth between our country and other countries along the Silk Road economic belt and the $21^{\text {st }}$ century maritime Silk Road, what talents should be fostered to meet the needs of the strategy of talent development ? There is no doubt that the graduates should master abundant and strong major knowledge, know about the international rule of doing business; qualify the excellent ability of practice and creation. Besides, they should be able to use foreign languages to communicate about major problems, which means the talents are the talents with high quality and multi-skills

\section{THE CONNOTATION OF CROSS--CULTURAL COMMUNICATION TALENTS WITH HIGH QUALITY AND MULTY-SKILLS}

High quality with cross-cultural talents mean owning comprehensive qualities which could also be called comprehensive presentation, containing all kinds of animation, knowledge, ability and the comprehensive stable qualifications in expert technology profession. It could be divided into five parts: physical attribute, psychological fitness, external quality, cultural quality and professional competence. Specifically, the comprehensive quality covers the knowledge level, moral civilization, all kinds of abilities and specialty. Meet the international environment and market with the changes. The talents who owned the cross-cultural quality could actively adapt themselves to the situation and deal with the pressure to confront the challenges, and grasp the chance to promote the international exchange and negotiations.

The cross--cultural talents was being defined relative to the single talents. To the non-foreign-language major students, the cross-culture talents could communicate with other people in English about the daily work and the major problem. As you know, to the foreign-language department students, the cross-culture talents are required to not only have the ability of speaking, listening, reading and translating to the one or more foreign language, but also know about the basic information, expert vocabulary and work process of other areas.

Then what is the cross--culture communication? The cross-culture communication means all the actives that happened when the talents with different culture background share the information, the feeling and the opinions. The scholar Chen Xin pointed out that the ability of cross--culture communication means the pragmatic competence and communication practice ability with the cross--culture communication consciousness when different culture background people are communicating.[1] Of course, the language ability means the listening ability, speaking ability, reading ability and translating ability. Then what is the pragmatic competence? The pragmatic competence means the users of the language use the language ability reasonably according to the special context, society and cultural factors. Next, we will talk about the communication 
practice ability. It contains language communication practice ability and non-communication practice ability, emphasizing the conversion of the language rule and the communication rule. The excellent cross-culture communication ability is the only correct approach to promote the international exchange, negotiations and co-operation.

\section{THE SITUATION ANALYSIS TO THE TALENT MARKETS}

\section{A. Our country is a developing country.}

We are tremendously inferior to the developed countries in the economic development level, science level and society welfare guarantee institution. [2]Therefore, many talents will not go back to their homeland if they had gone abroad. According to the data of the Education Department to the Book Blue of Chinese Overseas Students Return to the Motherland to Work, From 1978 to the end of 2013, the overseas from our country is about three million fifty-eight thousand and sis hundred, the amount of return after several years is one million four hundred and forty-four thousand and two hundred, only occupying the 47.22 percent of the total overseas. As we can get the conclusion that the outflow of the talent is more than half [3](Table I).

TABLE I. ( UNIT: TEN THOUSAND) THE ST ATICS OF GOING ABROAD AND RET URNING FROM 2010--2014

\begin{tabular}{lccc}
\hline Year & going abroad & return from abroad & non-return \\
\hline 2010 & 28.47 & 13.48 & 14.99 \\
\hline 2011 & 33.97 & 18.62 & 15.35 \\
\hline 2012 & 39.96 & 27.29 & 12.67 \\
\hline 2013 & 41.39 & 35.35 & 6.04 \\
\hline 2014 & 45.98 & 35.48 & 10.50 \\
\hline
\end{tabular}

The above statistics shows the data of overseas and returning to the birth place in recent 5 years. We could know that the amount of not returning to the birth place is high though the percent of not return and overseas were downtrend. The phenomenon of the draining of outstanding talents remains distressing.

\section{B. Serious shortage of application talents}

The graduates in recent 6 years is six million three hundred and ten thousand in 2010, six million six hundred thousand in 2011, six million eight hundred thousand in 2012, six million nine hundred and ninety thousand in 2013, seven million two hundred and seventy thousand in 2014, seven million four hundred and ninety thousand in 2015 . The amount of the graduates is increasing year after year, however, on one hand; many enterprises could not employ the suitable graduates to work for them. On the other hand, many graduates could not find the suitable job when they graduate from colleges. How to solve the contradictory phenomenon? On one hand, the undergraduate colleges should transform according to the need of the society and economic development, on the other hand, the students should master a special technology that will be useful to their profession. On the whole, the attraction of the professional education should be enhanced to the staff and the students. Only through this way could we meet with the needs of the enterprises in our country. Furthermore, we could reach the requirement to the international talents under the Silk Road economic belt and the $21^{\text {st }}$ century maritime Silk Road.

According to the data, more than twenty thousand students graduate from the colleges or universities every year. However, only little of them could be able to use foreign language to deal with the international business about the cross-culture communication. Besides, according to the data from the Foreign Language Bureau of China, at present, our country are very lack of integrated advanced talents of foreign languages in simultaneous interpretation and written translation. The shortage is completely undertaking the translation of between Chinese and foreign languages or between one foreign language and other foreign languages. It proves that the foreign language students have strong theory knowledge, and are good at obtaining in examination, but lack of practice ability, especially dealing with the international business, not able to meet the needs to the international foreign talents. Just so, some scholars have proposed that we are urgent to cultivate some new type foreign language talents with international vision, knowing about and familiar with the international business rules. They should have solid and comprehensive language knowledge. Up to now, only a little could reach the requirement.

\section{The single employees are surplus and the comprehensive talents are deficient}

Although talent is generally perceived as a combination of multiple components, the general outcome conceals the unilateral approaches to talent of the separate stakeholder groups.[4] Every year, more than one hundred million students register for the CET 4 or CET 6 examination, which have become a necessary task in college lives. Even many students prepare to take the examination on the first day of entering the colleges. Many students have taken the examination more than one time. What's more, some universities even put the English certification as a qualification to obtain the degree certificate. Of course, you will have advantage if you have passed CET 4 or CET 6 under the same conditions. As a result, English certification has become the new goal of college students. However, if we just know some simple English and prepare the examination just for the certification, we will be eliminated in the furious competition. Luckily, many college students have realized that the employees who just know about little knowledge will not gain popularity by the enterprises or companies. However, unluckily, only 30\%--40\% students could pass the CET 6 examination. Especially the engineering students, they could only use English to make simple dialogues, not able to discuss the special problem. Their knowledge is single type and it's hard to meet with the needs of the market. Even they passed English levels after hard working, then what's their oral English? Do they adapt to the need of the society? Oral English teaching is not satisfactory and many teachers face a problem of considering how to develop learners’ oral English Majors.[5]

To language students, especially English language students, just learning one language is hard to meet with the needs of the enterprises towards the elite talent. With the development of 
the society and the trend, the positions which only have requirements towards the language are less and less. Frankly speaking, the language is a tool which is used to communicate. As a result of the language specialty, the students who learn language just have single knowledge. With the initiative of the Silk Road economic belt and the $21^{\text {st }}$ century maritime Silk Road, the cooperation between one country and other country will get more and more closely in financial, sources, communication, agriculture, forestry, animal husbandry and fishery industry and emerging industry containing new-era information technology, biology, sea, new energy and materials. A growing number of employers acknowledge the peril of conducting business when talent management strategies are put on hold, according to Manpower's recent survey on the global labor market. Nearly eight out of 10 employers surveyed report that they are taking steps to grow their talent pools and access the skills that drive business results[6]. There is no doubt that the language students not only must grasp the language knowledge but also the expert knowledge in their future work areas, especially in the business management.

\section{The Paths to Foster the Cross-Culture COMMUNiCATION TALENT WITH High QUALITY}

\section{A. Attach importance to the spiritual civilization education}

Firstly, the schools and the government should pay attention to the cultivation of national spirit which put the patriotism as the core in basic education. In a long history, unyielding and great national spirit had formed in our country. The history has showed that the patriotism had become a principle line in our forward and the spirit backbone of all country's people. Through the patriotism education, we can enhance people's sense of identity, sense of belonging, sense of dignity and sense of honor.

Secondly, the schools and the government should pay attention to the cultivation of the students' national self-confidence. After reform and open, our country had experienced great changes; cultural soft power and comprehensive competition have been enhanced. So we should have confidence when we deal with trade with foreign countries. The strong selfconfidence could let us do business according to the rules and not be teased. We should spread Chinese culture consciously in the process of dealing with foreign countries, let Chinese culture "go out".

Finally, the schools and the government should make a point of ideological and moral education to inherit Chinese traditional virtue. The liberal education and major education must be combined to solve the shortage of our students' ability. In their later lives, they should go with "two legs", not just one. Just like a proverb says: a person who possesses high moral could be the general of the group. With the development of the science, the internet is a good way to carry out the moral education. The form could be new and the contents could be rich. If you have high virtue, we will success half in our career. Everyone doesn't like to work or live with a notorious person, and will none people help them if they have trouble. However, if you have good reputation, you will get much help from others containing living or working.

\section{B. Reform the courses in colleges or universities, enhance the quality of the staff}

Firstly, with the initiative of the Silk Road economic belt and the $21^{\text {st }}$ century maritime Silk Road, the exchange of our country with other countries will get more and more frequently in politic, economic and culture. The co-operation with other countries along the way will must depend on the exchange and communication. However, different countries have different value orientation, thinking ways, social rules and texture rules. If we are not familiar with the cultural background knowledge, we may fail in communicating, negotiations and breaking of co-operation relationship due to violate the taboos or express mistakenly. If we want to become a qualified talent in $21^{\text {st }}$ century, we must learn the value orientation and the thinking mode along the way which were formed in different culture background; we must learn the difference in role relationship and behavior rules due to the different structure. The most important is that we must remember and respect the difference to ensure the international co-operation go on without trouble.

Secondly, the university should emphasize the nonlanguage students to learn the major English of their major. Generally speaking, public English should be scheduled in the first term of the college study time to lay the foundation of major English learning later. When in sophomore and junior, special English related to their major will be scheduled to stand for the public English. For example, the students in law should learn legal English; the students in civil engineering should learn civil engineering English. Through the special English learning with their majors could not only stimulate the interest of learn English and improve their English level, but also enhance the competition ability to find a suitable job and meet with the needs to the international talents in $21^{\text {st }}$ century.

Thirdly, the university should emphasize the arrangement of practice course to enhance the ability of the students doing by them, which could enhance the practice ability and creation ability. At present, most universities put cultivating scholar talents as their goal, which is not suitable to the society's development. As a result, many enterprises or companies could not find suitable graduates to work for them; on the other hand, many graduates don't want to do the technological work due to the traditional idea. Generally speaking, the proportion of scholar talents and application talent should be 2:8; the cultivation structure meets with the needs of the society, so the ratio is our effort too.

Fourthly, the staff is the engineer of human souls, is the transmitters of the knowledge and civilization, are the fountainhead of the students. The staff with the international vision will have subtle influence towards the international vision of the students through what they teach. What is more, the cooperation relationship between our universities and foreign universities should be built as soon as possible.

\section{CONCLUSION}

The practice to the initiative of the Silk Road economic belt and the $21^{\text {st }}$ century maritime Silk Road have put the requirement to the cross-culture communication with high quality. The cultivation of the cross-culture communication with high quality is our goal of our education, which need the joint effort 
from the government, the schools and the enterprises. We must admit that the cultivation of the cross-culture communication with high quality have far to go. Countries aiming to attract talents from other countries should pay more attention to attract international students and encourage them to seek working opportunities in local employment markets after finishing study.[7]

\section{REFERENCES}

[1] Chen Xin, "the course arrangement from the point of cross-culture communication to explore the international foreign talents cultivation" [J]. Foreign Language World, 2012(5):73-78. (references)
[2] Wang Lujiang, "meeting the world to cultivate the creative talents with characters" [N]. China Education Paper, 2007. ( in Chinese)

[3] Zhao Yanan, "The oversea situation in 2013" [N]. China Education Department. 2013. ( in Chinese)

[4] M, Thunnissen, P, Van, Arensbergen, K. Elissa, “A multi-dimensional approach to talent,” Persinnel Review,2015,vol.44(2), pp.182-199

[5] Liu Ping, "on oral English teaching for Chinese English Majors From a constructive perspective,” Studies in Literature and Language, 2012, Vol.5 (3), pp.133-138

[6] Marsh, Lisa, “ Talent Shortages Worldwide Put Businesses at Peril,” T + D, 2013, Vol.67 (8), pp.16

[7] Hao Wei, An empirical study on the determinants of international student mobility: a global perspective. Higher Education, 2013, Vol.66 (1) pp.105-122 